\title{
Total mercury exposure risk and selenium content measuring on fishery products consumed by women of childbearing age from Bogota, Colombia
}

\author{
Riesgo de exposición a mercurio total y medición del \\ contenido de selenio en productos de la pesca consumidos \\ por mujeres en edad fértil de Bogotá, Colombia
}

MSc. Andrea del Pilar Mojica Cortes ${ }^{1}$, Esp. Jaime Alberto Guerrero Montilla ${ }^{2}$, MSc. Jhonny Eddison Vargas Hernández ${ }^{\circledR}$, MSc. Iván Camilo Sánchez Barrera² MSc. Luz Adriana Ruíz Pérez ${ }^{3}$, Esp. Diana Patricia Castro Aguilar ${ }^{3}$, MSc. Oscar Alberto Noreña Trigos ${ }^{3}$, Ing. Ruth Castellanos García ${ }^{4}$, Esp. Diana María Pérez Castiblanco ${ }^{4}$

JOURNAL VITAE

School of Pharmaceutical and Food Sciences ISSN 0121-4004 | ISSNe 2145-2660

University of Antioquia Medellin, Colombia

Filliations

${ }^{1}$ Risk Assessment in Food Safety and

Pesticides Group. National Health Institute (INS). Bogota D.C., Colombia.

${ }^{2}$ Applied Epidemiology Research Group. National Health Institute (INS). Bogota D.C., Colombia.

${ }^{3}$ Public Health Division. District Health Department (SDS). Bogota DC, Colombia.

${ }^{4}$ Health Risk Management Direction. South Local District Health Department. Bogota DC, Colombia.

*Corresponding Oscar Alberto Noreña Trigos oanorena@saludcapital.gov.co

Received: 10 June 2021 Accepted: 27 September 2021 Published: 14 October 2021

\begin{abstract}
Background: Dietary exposure to mercury in women of childbearing age could result in neurological effects on the fetus. A health risk assessment of total mercury by fishery products intake has not been conducted in this population group in Bogota, Colombia. On the other hand, it has been suggested that selenium content on fishery products may have a protective effect against mercury toxicity. Nevertheless, selenium content on fish species marketed in Bogota has not been determined. Objective: Exposure risk to total mercury and selenium content on fishery products consumed by women of childbearing age from Bogota, Colombia, were assessed. Methods: Total mercury and selenium concentrations for products available at fish stores and supermarkets were determined. The exposure risk to total mercury was estimated considering the intake of these products by women of childbearing age group. Results: Total mercury highest concentrations were $0.8166 \mathrm{mg} / \mathrm{kg}$ in mota (Calophysus macropterus), and $0.6275 \mathrm{mg} / \mathrm{kg}$ in catfish (Pseudoplatystoma tigrinum). On the other hand, the highest selenium concentration was $0.6471 \mathrm{mg} / \mathrm{kg}$ in nicuro (Pimelodus blochii). Finally, it was established that for women of childbearing age group, health risk of exposure to total mercury due to mota intake exceeded by 8.56 -fold the reference dose. Conclusions: Mota intake considerably increases exposure risk to total mercury on women of childbearing age from Bogota, Colombia. The selenium levels established in the fishery products assessed, except for catfish and mota, are theoretically suggestive of a protective effect of selenium against mercury toxicity. Consequently, continuous total mercury concentrations monitoring is required to protect health of women of childbearing age and the general population from Bogota, Colombia.
\end{abstract}

Keywords: women of childbearing age, fishery products, mercury, selenium, risk assessment 


\section{RESUMEN}

Antecedentes: La exposición dietética al mercurio en mujeres en edad fértil podría provocar efectos neurológicos en el feto. En Bogotá, Colombia no se han realizado evaluaciones de riesgo por la exposición al mercurio total debido a la ingesta de productos de la pesca en este grupo de la población. Por otro lado, ha sido sugerido que el contenido de selenio en los productos de la pesca podría tener un efecto protector frente a la toxicidad por mercurio, sin embargo, el contenido de selenio en las especies de peces comercializadas en Bogotá, Colombia no ha sido determinado. Objetivo: Evaluar el riesgo de exposición al mercurio total y el contenido de selenio en los productos de la pesca consumidos por las mujeres en edad fértil de Bogotá, Colombia. Métodos: Se determinaron las concentraciones de mercurio total y selenio en distintos productos de la pesca disponibles en pescaderías y supermercados. El riesgo de exposición a mercurio total se estimó considerando la ingesta de estos productos por parte de un grupo de mujeres en edad fértil. Resultados: Las concentraciones más altas de mercurio total fueron de $0.8166 \mathrm{mg} / \mathrm{kg}$ en mota (Calophysus macropterus) y $0.6275 \mathrm{mg} / \mathrm{kg}$ en bagre (Pseudoplatystoma tigrinum). Por otro lado, la concentración más alta de selenio fue de $0.6471 \mathrm{mg} / \mathrm{kg}$ en nicuro (Pimelodus blochii). Finalmente, se estableció que el riesgo de exposición a mercurio total, debido a la ingesta de mota, excedió en 8.56 veces la dosis de referencia en el grupo de mujeres en edad fértil. Conclusiones: La ingesta de mota aumenta el riesgo de exposición al mercurio total en las mujeres en edad fértil de Bogotá, Colombia. Por otro lado, los niveles de selenio identificados en los productos evaluados, excepto en bagre y mota, teóricamente sugieren un posible efecto protector del selenio contra la toxicidad por mercurio. Considerando lo indicado, es necesario realizar un monitoreo continuo de las concentraciones de mercurio total en los productos de la pesca, con el fin de proteger la salud de las mujeres en edad fértil y de la población general de Bogotá, Colombia.

Palabras clave: mujeres en edad fértil, productos de la pesca, mercurio, selenio, evaluación de riesgo

\section{INTRODUCTION}

Mercury is found in the environment as a result of natural and human activities. Most mercury in the atmosphere is elemental mercury vapor, while the mercury in water, soil, sediments, or plants and animals is found as inorganic mercury salts and organic forms of mercury, like methylmercury. Mercury accumulates most efficiently in the aquatic food web. Nearly all mercury that accumulates in fish tissue is methylmercury. Inorganic mercury does not tend to bioaccumulate (1-4).

Dietary methylmercury is efficiently absorbed in the blood and readily distributed to all tissues, including the brain; it crosses the placental barrier, affecting fetuses' neurological development. Mercury exposure has been linked to low birth weight and limitations related to motor function, visual processing, verbal ability, memory, behavior, and intelligence quotient (IQ) alterations, as well as to attention disorders, among others (5-10).

A reference dose has been established to protect human health so, when ingested daily over a lifetime, has no adverse health effects to humans, including sensitive population groups. Since the developing fetus exposure to methylmercury, beyond the reference dose, may result in neurotoxic effects, women of childbearing age are considered a priority population group (5-10).

Fish and shellfish intake is the most important source of mercury exposure in humans. The mercury bioaccumulation in tissues of those organisms is caused by biomagnification, which means a mercury concentration increases as it moves up through the aquatic trophic chain. Accordingly, the mercury concentration is lowest in sedimentary microorganisms and higher in predator species of large size (1-4).

Measurement of mercury concentrations in fishery products has been carried out since years ago worldwide, allowing the availability of average mercury concentrations for different species. On the other hand, scientific literature has established that mercury toxicity can be counteracted by selenium content found in fish and shellfish tissues. This raises the need to establish the selenium concentration in fishery products, its molar relationship to mercury, and the extent of its potential protective effects against mercury toxicity (11-16).

In this research, total mercury and selenium concentration were determined in fishery products eaten by women of childbearing age from Bogota, Colombia. Moreover, the risk exposure to total mercury link to fishery products intake in this population group was characterized. Currently, no information in this regard is available, although these data are key parameters for public health policy implementation.

\section{MATERIALS AND METHODS}

\section{Fishery products}

Fishery products included in this investigation were tuna (Thunnus thynnus), catfish (Pseudoplatystoma tigrinum), tilapia (Oreochromis sp), bocachico (Prochilodus magdalenae), nicuro (Pimelodus blochii), sardine (Sardinops sagax), salmon (Salmo salar), 
pangasius (Pangasius bocourti), mota (Calophysus macropterus) and trout (Oncorhynchus mykiss). These were selected considering consumption frequency, ingested portion size, purchasing, and consumption place, among other factors based on the results of a previous study in which the consumption of fishery products in women of childbearing age from Bogotá, Colombia was assessed (17).

\section{Sample size calculation}

Open Epi version 3.01 was used to calculate the sample size. Parameters considered for the calculation were a finite population of $1,000,000, a$ design effect of 1.0, a prevalence of total mercury in fishery products equal to 0.20 , an accuracy of 3 $\%$, and a reliability coefficient of $95 \%$.

The estimated sample consisted of 700 specimens. The number of individuals samples per fishery product was 120 for tuna, 110 for catfish, 90 for tilapia and bocachico, 70 for nicuro, 60 for sardine, 50 for salmon and pangasius, 40 for mota, and 20 for trout. This was determined through a stratified procedure, in which a 1 to 10 score was assigned based on consumption frequency, and another 1 to 2 according to intake risk. In the latter case, the assigned score was done considering scientific evidence related (Table S1).

\section{Fishery products collection, storage, and transport}

Samples were obtained at fish stores and supermarkets located in Bogota, Colombia. The minimum quantity collected for each fishery product was $250 \mathrm{~g}$. Canned products, tuna, and sardines, were collected as commercial units equivalent to the same sample mass.

Fresh and frozen product samples were packed, hermetically sealed, and labeled within polyethylene bags. These were stored in portable fridges equipped with cooling gels to maintain a maximum temperature of $8{ }^{\circ} \mathrm{C}$. Commercial units of canned products were kept away from sunlight, heat, and hitting.

Finally, samples were transported to facilities of the Public Health Laboratory in Bogota District Health Department. In this place, samples were stored in portable fridges and were frozen until further analysis.

\section{Preparation of fishery products samples}

Non-canned samples were defrosted, bone parts were removed, and the remaining material was put into a mixer to obtain a homogeneous material after 10 minutes of treatment. Canned samples were taken out of their packaging and homogenized for 5 minutes. The resulting material was poured into plastic bags that were properly labeled and stored, for no more than 3 days, at a temperature range of 2 to $4^{\circ} \mathrm{C}$.

\section{Mercury determination}

Measuring total mercury content was conducted without previous sample digestion, but through thermal decomposition, amalgamation, and atomic absorption spectrophotometry (US EPA method 7473), using a Direct Mercury Analyzer (DMA80 Milestone). $100 \mathrm{mg}$ of homogenized sample weighted in a clean and dry quartz cell were introduced into the analyzer and processed through a drying phase at $160^{\circ} \mathrm{C}$ for $30 \mathrm{~s}$; a decomposition stage at $160{ }^{\circ} \mathrm{C}$ for $70 \mathrm{~s}$; a catalytic step at $650{ }^{\circ} \mathrm{C}$ for $45 \mathrm{~s}$, and the amalgam breakdown at $650{ }^{\circ} \mathrm{C}$ for $150 \mathrm{~s}$. All sample analyses were duplicated. The estimated test detection limit was $0.0001 \mathrm{mg} / \mathrm{kg}$, and the established quantification limit was $0.001 \mathrm{mg} / \mathrm{kg}$.

\section{Selenium determination}

Selenium measurement was performed by Zeeman graphite furnace atomic absorption spectroscopy using the ICE 3400 equipment (Thermo Fisher). The analysis procedure included mixing $1 \mathrm{~g}$ of homogenized sample with $5 \mathrm{ml}$ nitric acid in a $50 \mathrm{ml}$ conical tube kept overnight at ambient temperature. Further, the tube was heated at $70^{\circ} \mathrm{C}$ for 75 minutes in a thermostatic bath, then it was allowed to cool at ambient temperature, and its total volume was completed with deionized water.

Eventually, the resultant material was poured into a $10 \mathrm{ml}$ volumetric flask containing $500 \mu \mathrm{L}$ of $2 \%$ nickel nitrate solution used as a matrix modifier. After that, $20 \mu \mathrm{L}$ of the mixture were injected into the ICE 3400 equipment for analysis. First, a drying stage was conducted at $100{ }^{\circ} \mathrm{C}$ for $40 \mathrm{~s}$, followed by calcination at $1,000{ }^{\circ} \mathrm{C}$ for $170 \mathrm{~s}$, atomization at $2,200^{\circ} \mathrm{C}$ for $3 \mathrm{~s}$, and cleaning at $2,500^{\circ} \mathrm{C}$ during $3 \mathrm{~s}$.

The analysis was conducted using duplicate samples. The estimated test detection limit was $0.005 \mathrm{mg} / \mathrm{kg}$, and the established quantification limit was $0.01 \mathrm{mg} / \mathrm{kg}$. 


\section{Se:Hg molar ratio and molar excess of selenium}

Selenium and mercury concentrations were used to calculate moles for each element. Selenium to mercury molar ratio (Se:Hg) was obtained calculating a simple molar proportion corresponding to each sample and fishery product analyzed. The molar excess of selenium was estimated by subtracting the number of mercury moles from those of selenium found on each sample and fishery product analyzed.

\section{Exposure assessment and risk characterization}

Exposure assessment was conducted using @RISK program version 5, developed by Palisade Corporation. The mathematical expression used considers food intake, mercury concentration in food, body weight $(\mathrm{bw})$, absorption $\left(\mathrm{F}_{\mathrm{abs}}\right)$, and exposure $\left(\mathrm{F}_{\mathrm{exp}}\right)$ factors. The abovementioned factors were considered constants, assuming the maximum possible value for the worstcase scenario (Equation 1).

$$
\begin{gathered}
\text { Exposition }=(\text { Intake }(g / d) x \\
\text { Concentration }(\mathrm{mg} / \mathrm{kg}) \times \\
\left.F_{a b s} \times F_{\text {exp }}\right) /(\text { Body weigth }(\mathrm{kg}))
\end{gathered}
$$

Equation 1

Intake and body weight data were obtained from a previous study (17). Fishery products intake was established from a sample of 1,015 women of childbearing age surveyed in Bogota, Colombia (17). The food intake data for each fishery product was normalized to a gram per day unity $(\mathrm{g} / \mathrm{d})$, considering portion size (Table S2), number of ingested portions, and frequency factor (Table S3) as shown in Equation 2.

\section{Intake $(g / d)=$ Portion size $(g) \times$ Number of portions $x$ Frequency factor}

Equation 2

Single point and probabilistic estimations were obtained, according to data availability. The probabilistic ones considered a minimum of 20 data points. The best fit model for food intake data, total mercury content in food, and body weight were selected based on Akaike Information Criterion (AIC). Probabilistic estimations required 10,000 Monte Carlo iterations.
The hazard coefficient calculation (Equation 3 ) estimates risk due to total mercury dividing exposure extent by the toxicological reference dose (RfD). The RfD corresponds to the provisional tolerable weekly intake (PTWI) to total mercury (4 $\mu \mathrm{g} / \mathrm{kg}$ bw) recommended by the Joint FAO/WHO Expert Committee on Food Additives (JECFA), which was expressed as a daily intake value $(5.7 \mathrm{x}$ $10^{-4} \mathrm{mg} / \mathrm{kg} \mathrm{bw}$ ) (18).

\section{Hazard coefficient $=$ Exposure $/\left(R_{f} D\right) \quad$ Equation 3}

\section{Statistical analysis}

Statistical analysis for mercury and selenium content, as well as for Se:Hg molar ratio and molar excess of selenium was performed using SPSS, version 22 (IBM) statistical package. In all cases, statistical significance was selected at $\alpha=0.05$ with a confidence interval of $95 \%$. Data distribution normality was assessed using ShapiroWilk or Kolmogorov-Smirnov tests, depending on sample size in the groups. Homoscedasticity (equality of variances) was determined employing the Levene test. The Welch test estimated the contrast between groups as variances were not equal among these. Finally, Games-Howell posthoc test was used to identify the groups in which statistically significant differences occurred.

\section{RESULTS}

Mean total mercury concentration for mota $\left(0.8166 \mathrm{mg} / \mathrm{kg}, \mathrm{Cl}_{95 \%}\right.$ [0.6864 to 0.9469$\left.]\right)$ and catfish $\left(0.6275 \mathrm{mg} / \mathrm{kg}, \mathrm{Cl}_{95 \%}\right.$ [0.5512 to 0.7038$\left.]\right)$ was high, while its lowest values corresponded to pangasius $\left(0.0207 \mathrm{mg} / \mathrm{kg}, \mathrm{Cl}_{95 \%}\right.$ [-0.0071 a 0.0485$\left.]\right)$ and tilapia (0.0194 mg/kg, Cl ${ }_{95 \%}$ [0.0168 to 0.0220$\left.]\right)$. In general, there were statistically significant differences among total mercury mean contents for all fishery products $(F=66.8, p<0.05)$, being especially noticeable when comparing mota and catfish to other species (Figure 1, Table S4). 


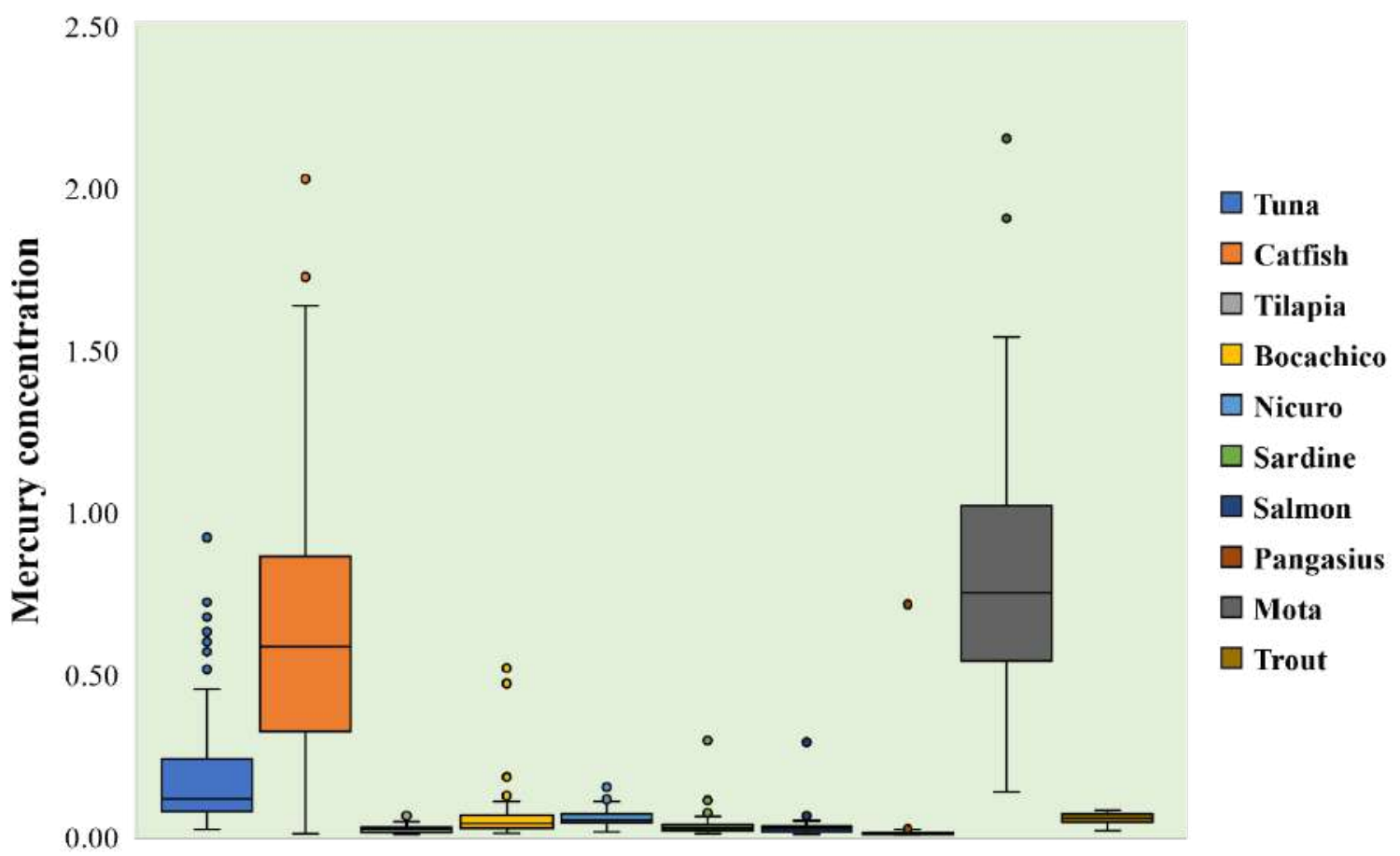

Figure 1. Total mercury concentrations in fishery products. The total mercury levels are expressed as milligram of element over kilogram of product $(\mathrm{mg} / \mathrm{kg})$.

Regarding selenium, the highest mean concentration was observed for nicuro $\left(0.6471 \mathrm{mg} / \mathrm{kg}, \mathrm{Cl}_{95 \%}[0.5500\right.$ to 0.7442$])$, whereas the lowest mean selenium contents corresponded to salmon $(0.1121 \mathrm{mg} / \mathrm{kg}$, $\mathrm{Cl}_{95 \%}$ [0.0888 to 0.1354$\left.]\right)$ and pangasius $(0.1003$ $\mathrm{mg} / \mathrm{kg}, \mathrm{Cl}_{95 \%}[0.0884$ to 0.1122$\left.]\right)$. There were statistically significant differences among mean selenium contents for all fishery products ( $F=78.8$, $\mathrm{p}<0.05)$. The highest extent for these differences was observed for nicuro compared to other species (Figure 2, Table S5).

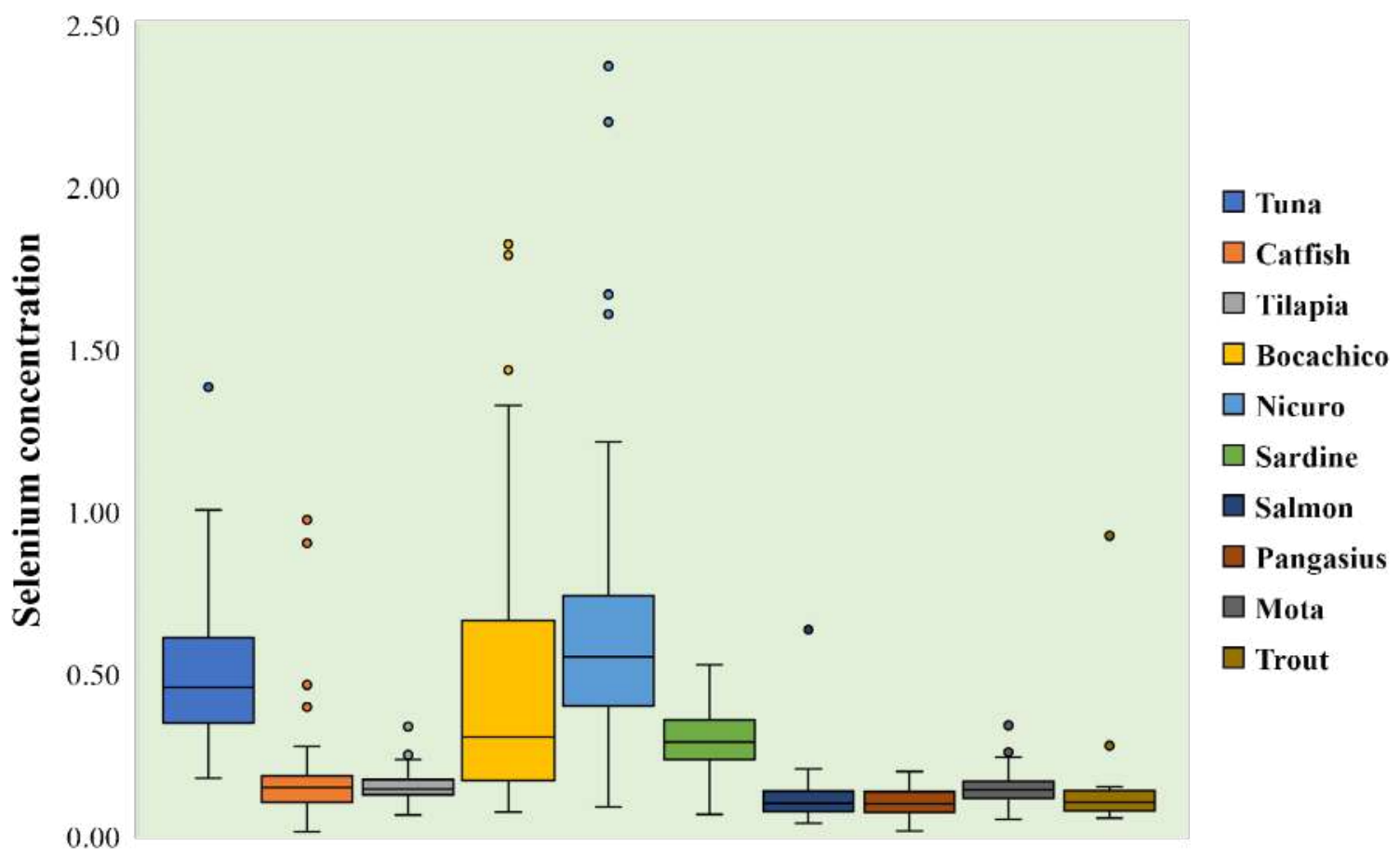

Figure 2. Selenium concentrations in fishery products. Selenium levels are expressed as milligram of element over kilogram of product $(\mathrm{mg} / \mathrm{kg})$. 
The highest Se:Hg molar ratio was found for pangasius $\left(60.16, \mathrm{Cl}_{95 \%}[48.25\right.$ to 72.07$\left.]\right)$, and the lowest corresponded to catfish $\left(2.91, \mathrm{Cl}_{95 \%}[0.46\right.$ to 5.37]) and mota $\left(0.63, \mathrm{Cl}_{95 \%}[0.40\right.$ to 0.86$\left.]\right)$. There were statistically significant differences among mean
Se:Hg molar ratio for all fishery products $(F=83.5$, $\mathrm{p}<0.05)$. The highest extent for these differences was observed for pangasius and mota compared to other species (Figure 3, Table S6).

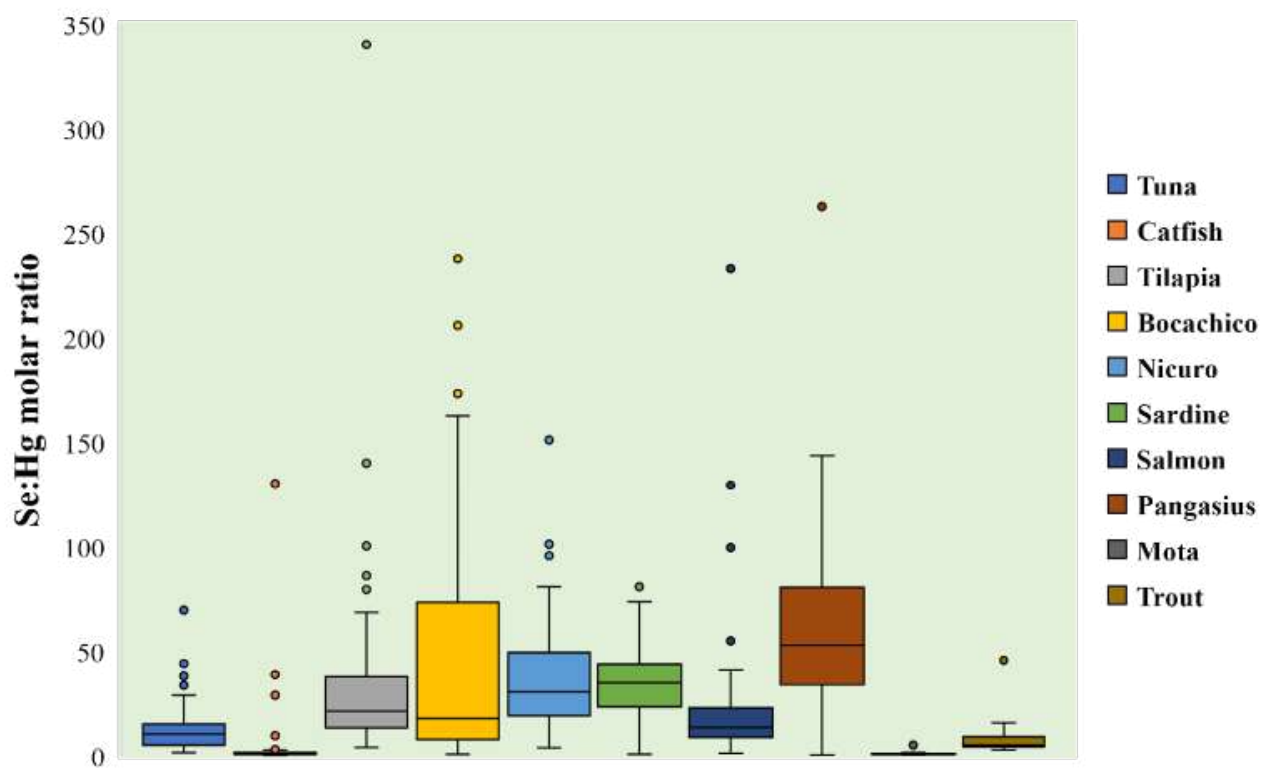

Figure 3. Se:Hg molar ratio in fishery products. Molar ratio is expressed as the fraction of selenium moles over mercury moles.

Considering the molar excess of selenium in fishery products sampled, the highest positive balances were found for nicuro $\left(0.0079 \mathrm{~mol} / \mathrm{kg}, \mathrm{Cl}_{95 \%}[0.0067\right.$ to 0.0091$])$, bocachico $\left(0,0055 \mathrm{~mol} / \mathrm{kg}, \mathrm{Cl}_{95 \%}[0,0045\right.$ to 0,0066$])$ and tuna $\left(0.0053 \mathrm{~mol} / \mathrm{kg}, \mathrm{Cl}_{95 \%}[0.0048\right.$ to 0.0057$])$, whereas the most negative balances were registered for catfish $\left(-0.0011 \mathrm{~mol} / \mathrm{kg}, \mathrm{Cl}_{95 \%}\right.$
[-0.0017 to -0.0066$])$ and mota $(-0.0023 \mathrm{~mol} / \mathrm{kg}$, $\mathrm{Cl}_{95 \%}[-0.0029$ to -0.0016$\left.]\right)$. There were statistically significant differences among mean molar excess of selenium for all fishery products ( $F=84.9, \mathrm{p}$ $<0.05)$. The highest extent of these differences corresponded to nicuro and mota when compared to the rest of species (Figure 4, Table S7).

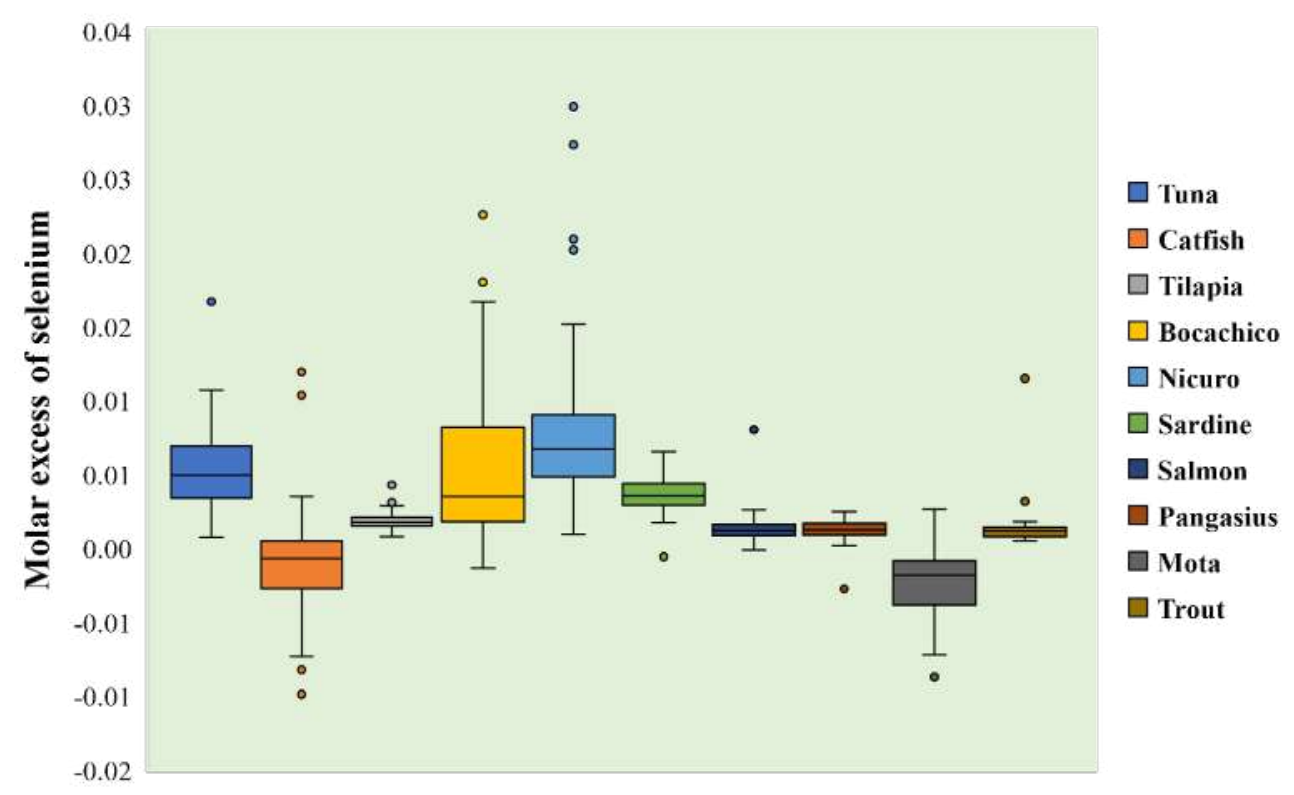

Figure 4. Molar excess of selenium in fishery products. Molar excess of selenium is expressed as mol of element over kilogram of product (mol/kg). 
Finally, the risk characterization showed that dietary exposure to total mercury in women of childbearing age was lower than the reference dose in most of the samples of the fishery products analyzed. In the mota case, dietary exposure risk to total mercury was considerably highest than the reference dose (Table 1).

Table 1. Exposure assessment and risk characterization to total mercury in fishery products

\begin{tabular}{lcc}
\hline Fishery product & Exposition $\mathbf{P}_{\mathbf{9 5}}$ ( $\mathbf{m g} / \mathbf{k g}$ bw/day) & Risk $\mathbf{P}_{\mathbf{9 5}}$ \\
\hline Tuna & $1.20 \times 10^{-4}$ & 0.224 \\
Catfish & $4.90 \times 10^{-4}$ & 0.870 \\
Tilapia & $2.11 \times 10^{-5}$ & 0.037 \\
Bocachico & $8.25 \times 10^{-5}$ & 0.145 \\
Nicuro & $2.72 \times 10^{-5}$ & 0.047 \\
Sardines & $8.98 \times 10^{-6}$ & 0.016 \\
Salmon & $1.00 \times 10^{-4}$ & 0.186 \\
Pangasius & $5.07 \times 10^{-6}$ & 0.009 \\
Mota & $4.88 \times 10^{-3}$ & 8.566 \\
Trout & $1.41 \times 10^{-4}$ & 0.247 \\
\hline
\end{tabular}

Note. The exposure was established considering food intake, mercury concentration in food, individual's body weight, absorption factor, and exposure factor. On the other hand, the risk was estimated through the calculation of the hazard coefficient.

\section{DISCUSSION}

The mean total mercury concentration for the fishery products sampled in this research ranged from 0.0194 to $0.8166 \mathrm{mg} / \mathrm{kg}$. The upper limit lies below the interval 0.02 to $2.45 \mathrm{mg} / \mathrm{kg}$ reported in a previous review on mercury contents for different fish species from 12 departments of Colombia (19). Considering selenium, its mean concentration in the fishery products sampled varied around 0.10 to 0.65 $\mathrm{mg} / \mathrm{kg}$; these values are alike to those registered in fishes from Brazil (0.02 - 0.44) (20) and Croatia $(0.18$ - 1.12) (21) and lower than those determined in fish from Turkey $(0.96-1.86)(22)$, United States (0.96 - 11.45) (23) and Argentina (0.47 - 4.57) (24).

There were statistically significant differences between total mercury and selenium mean concentrations. However, no exploration of the reasons behind these differences was attempted. It has been described in the scientific literature that mercury and selenium concentrations in fish tissues depend on its environmental bioavailability, bioaccumulation capacity of aquatic microorganisms, age, sex, size, and species location within the trophic chain, among others (25-29).
According to Colombian regulations, the maximum total mercury concentration allowed in fish and shellfish is $0.5-1.0 \mathrm{mg} / \mathrm{kg}$, depending on the species type assessed (30). It was evidenced that mean concentration of total mercury in catfish and mota exceeded the allowed level of $0.5 \mathrm{mg} / \mathrm{kg}$. Further, $66.0 \%$ and $77.0 \%$ of the samples collected from these species, respectively, surpassed this legal threshold value.

For selenium, a threshold value in fish and shellfish has not been established in Colombia. However, in the scientific literature has been described that a selenium excess content in fish tissues could have a protective effect against mercury toxicity. The high affinity between both elements and the selenium properties to reduce mercury gastrointestinal absorption, transform organic mercury into inorganic forms, produce stable and inert complexes, and redistribute mercury to less sensitive organs, are some mechanisms stated to explain this protective effect (15-16).

Se:Hg molar ratio and molar excess of selenium have been suggested as indicative parameters of protective effects of selenium against mercury toxicity (13-14). However, whether these parameters are sufficiently robust to represent the potential protective effect of this chemical element is still under discussion, so its role on mercury exposure risk assessment is not completely accepted yet (3132). Therefore, results obtained for both parameters in this research showed that a protective effect against mercury toxicity could be offered by intake of the fishery products assessed, except for catfish and mota. No additional analysis on the protective effect of selenium was intended.

It was found that women of childbearing age risk exposure to total mercury by intake of the fishery products analyzed was lower than the daily reference dose $\left(5.7 \times 10^{-4} \mathrm{mg} / \mathrm{kg} \mathrm{bw}\right)$ (18). However, the dietary exposure risk estimated for mota exceeded this threshold by 8.56 -fold. In this regard, a previous study found that bocachico (Prochilodus magdalenae) and corroncho (Chaetostoma spp.) intake, in two Valle del Cauca department townships, represented a relatively high dietary exposure risk to total mercury for the lactating women population, since the reference dose value was also exceeded (33).

Additionally, in a recently published research, mercury concentrations in blood, urine, and hair samples from a women group in the Mojana region were higher than the allowed maximum value in $62.8 \%$ of the cases. The study also pointed out 
that mercury concentration was higher for women who reported a relatively high fish consumption frequency than those who did not. Further, multiple regression models described that those women with daily fish intake had 33-fold higher mercury concentration in hair samples than those who did not report the daily intake of this food (34).

Finally, a continuous mercury concentration monitoring program in fishery products marketed for consumption in Bogota, Colombia, is required. This will allow permanent data updating, aiming to conduct an appropriate dietary exposure risk assessment of the women of childbearing age and the general population, since some fishery products available are captured from water bodies contaminated with mercury.

\section{CONCLUSIONS}

Mota intake considerably increases exposure risk to total mercury in women of childbearing age from Bogota, Colombia. The selenium levels established in the fishery products assessed, except for catfish and mota, are theoretically suggestive of a protective effect of selenium against mercury toxicity. Consequently, continuous total mercury concentrations monitoring is required to protect the health of the women of childbearing age and the general population from Bogota, Colombia.

\section{CONFLICT OF INTEREST}

The authors declare that there is no conflict of interest.

\section{ACKNOWLEDGMENTS}

This work was supported by the District Health Financial Fund (FFDS) through the Public Health Plan for Collective Interventions (Grant Number 7523).

\section{AUTHORS' CONTRIBUTIONS}

All authors participated equally in the development and writing of this research.

\section{REFERENCES}

1. Beckers F, Rinklebe J. Cycling of Mercury in the environment: Sources, fate, and human health implications: A review. Crit Rev Environ Sci Technol. 2017;47(9): 693-794. DOI: https://doi.org/1 $0.1080 / 10643389.2017 .1326277$

2. Driscoll CT, Mason RP, Chan HM, Jacob DJ, Pirrone N. Mercury as a global pollutant: Sources, pathways, and effects. Environ Sci
Technol. 2013;47(10):4967-4983. DOI: https://doi.org/10.1021/ es305071v

3. Eagles-Smith CA, Silbergeld EK, Basu N, Bustamante P, DiazBarriga F, Hopkins WA, et al. Modulators of mercury risk to wild life and humans in the context of rapid global change. Ambio. 2018;47:170-197. DOI: https://doi.org/10.1007/s13280-017-1011-x

4. Obrist D, Kirk JL, Zhang L, Sunderland EM, Jiskra M, Selin NE. A review of global environmental mercury processes in response to human and natural perturbations: Changes of emissions, climate, and land use. Ambio. 2018;47:116-140. DOI: https://doi. org/10.1007/s13280-017-1004-9

5. Bridges CC, Zalups RK. The aging kidney and the nephrotoxic effects of Mercury. J Toxicol Environ Health B Crit Rev. 2017;20(2):55-80. DOI: https://doi.org/10.1080/10937404.201 6.1243501

6. Fernandes-Azevedo B, Barros-Furieri L, Peçanha FMI, Wiggers GA, Frizera-Vassallo P, Ronacher-Simões $M$, et al. Toxic effects of Mercury on the cardiovascular and central nervous systems. J Biomed Biotechnol. 2012. DOI: https://doi. org/10.1155/2012/949048

7. Genchi G, Sinicropi M, Carocci A, Lauria G, Catalano A. Mercury Exposure and Heart Diseases. Int J Environ Res Public Health. 2017;14(1):74. DOI: https://doi.org/10.3390/ijerph14010074

8. Ha E, Basu N, Bose-O'Reilly S, Dórea JG, McSorley E, Sakamoto $M$, et al. Current progress on understanding the impact of Mercury on human health. Environ Res. 2017;152:419-433. DOI: https://doi.org/10.1016/j.envres.2016.06.042

9. Kim KH, Kabir E, Jahan SA. A review on the distribution of $\mathrm{Hg}$ in the environment and its human health impacts. Hazard Mater. 2016;306:376-385. DOI: https://doi.org/10.1016/j. jhazmat.2015.11.031

10. Maqbool F, Niaz K, Hassan FI, Khan F, Abdollahi M. Immunotoxicity of Mercury: Pathological and toxicological effects. J Environ Sci Heal C. 2017;35(1):29-46. DOI: https://doi.org/10.1080/105905 01.2016.1278299

11. Bjørklund G, Aaseth J, Ajsuvakova OP, Nikonorov AA, Skalny A V., Skalnaya MG, et al. Molecular interaction between Mercury and selenium in neurotoxicity. Coord Chem Rev. 2017;332:30-37. DOI: https://doi.org/10.1016/j.ccr.2016.10.009

12. Khan MAK, Wang F. Mercury-selenium compounds and their toxicological significance: Toward a molecular understanding of the mercury-selenium antagonism. Environ Toxicol Chem. 2009;28(8):1567-1577. DOI: https://doi.org/10.1897/08-375.1

13. Ralston NVC, Blackwell JL, Raymond LJ. Importance of molar ratios in selenium-dependent protection against methylmercury toxicity. Biol Trace Elem Res. 2007;119:255-268. DOI: https://doi. org/10.1007/s12011-007-8005-7

14. Kaneko JJ, Ralston NVC. Selenium and Mercury in Pelagic Fish in the Central North Pacific Near Hawaii. Biol Trace Elem Res. 2007;119:242-254. DOI: https://doi.org/10.1007/s12011-007$8004-8$

15. Ralston NVC, Raymond LJ. Dietary selenium's protective effects against methylmercury toxicity. Toxicology. 2010;278(1):112-123. DOI: https://doi.org/10.1016/j.tox.2010.06.004

16. Spiller HA. Rethinking Mercury: the role of selenium in the pathophysiology of mercury toxicity. Clin Toxicol (Phila). 2018;56(5):313-326. DOI: https://doi.org/10.1080/15563650.20 17.1400555

17. Hospital de Vista Hermosa - ESE. Caracterización de hábitos de consumo de productos de la pesca en mujeres en edad fértil de Bogotá D.C. Bogotá; 2016. 
18. Joint FAO/WHO Expert Committee on Food Additives (JECFA) Mercury. https://apps.who.int/food-additives-contaminantsjecfa-database/chemical.aspx?chemID=1806. 2011 (Accessed 17 August 2021)

19. Vargas-Licona PS, Marrugo-Negrete JL. Mercurio, metilmercurio y otros metales pesados en peces de Colombia: riesgo por ingesta. Acta biol Colomb. 2019;24(2):232. DOI: https://doi. org/10.15446/abc.v24n2.74128

20. Lino AS, Kasper D, Guida YS, Thomaz JR, Malm O. Mercury and selenium in fishes from the Tapajós River in the Brazilian Amazon: An evaluation of human exposure. J Trace Elem Med Biol. 2018;48:196-201. DOI: https://doi.org/10.1016/j. jtemb.2018.04.012

21. Grgec AS, Kljaković-Gašpić $Z$, Orct $T$, Tičina $V$, Sekovanić $A$, Jurasović J, et al. Mercury and selenium in fish from the eastern part of the Adriatic Sea: A risk-benefit assessment in vulnerable population groups. Chemosphere. 2020;261:127742. DOI: https:// doi.org/10.1016/j.chemosphere.2020.127742

22. Ulusoy Ş, Mol S, Karakulak FS, Kahraman AE. Selenium-Mercury Balance in Commercial Fish Species from the Turkish Waters. Bio Trace Elem Res. 2019;191:207-213. DOI: https://doi.org/10.1007/ s12011-018-1609-2

23. Day NK, Schmidt TS, Roberts JJ, Osmundson BC, Willacker JJ, Eagles-Smith CA. Mercury and selenium concentrations in fishes of the Upper Colorado River Basin, southwestern United States: A retrospective assessment. PLoS One. 2020;15(1):e0226824. DOI: https://doi.org/10.1371/journal.pone.0226824

24. Arcagni M, Rizzo A, Juncos R, Pavlin M, Campbell LM, Arribére MA, et al. Mercury and selenium in the food web of Lake Nahue Huapi, Patagonia, Argentina. Chemosphere. 2017;166:163-173. DOI: https://doi.org/10.1016/j.chemosphere.2016.09.085

25. Ahonen SA, Hayden B, Leppänen JJ, Kahilainen KK. Climate and productivity affect total mercury concentration and bioaccumulation rate of fish along a spatial gradient of subarctic lakes. Sci Total Environ. 2018;637-638:1586-1596. DOI: https:// doi.org/10.1016/j.scitotenv.2018.04.436
26. Bastos WR, Dórea JG, Bernardi JVE, Manzatto AG, Mussy MH, Lauthartte LC, et al. Sex-related mercury bioaccumulation in fish from the Madeira River, Amazon. Environ Res. 2016;144(Part A):73-80. DOI: https://doi.org/10.1016/j.envres.2015.11.001

27. Donald DB, Wissel B, Anas MUM. Species-specific mercury bioaccumulation in a diverse fish community. Environ Toxicol Chem. 2015;34(12):2846-2855. DOI: https://doi.org/10.1002/ etc. 3130

28. Poste AE, Muir DCG, Guildford SJ, Hecky RE. Bioaccumulation and biomagnification of Mercury in African lakes: The importance of trophic status. Sci Total Environ. 2015;506-507:126-136. DOI: https://doi.org/10.1016/j.scitotenv.2014.10.094

29. Wang $X$, Wang $W X$. The three ' $B$ ' of fish mercury in China: Bioaccumulation, biodynamics and biotransformation. Environ Pollut. 2019;250:216-232. DOI: https://doi.org/10.1016/j. envpol.2019.04.034

30. Ministerio de Salud y Protección Social (Minsalud). Resolución 122. Bogotá; 2012.

31. Gerson JR, Walters DM, Eagles-Smith CA, Bernhardt ES, Brandt JE. Do Two Wrongs Make a Right? Persistent Uncertainties Regarding Environmental Selenium-Mercury Interactions. Environ Sci Technol. 2020;54(15):9228-9234. DOI: https://doi. org/10.1021/acs.est.0c01894

32. Gochfeld, M, Burger J. Mercury interactions with selenium and sulfur and the relevance of the Se:Hg molar ratio to fish consumption advice. Environ Sci Pollut Res. 2021;28:1840718420. DOI: https://doi.org/10.1007/s11356-021-12361-7

33. Zapata-Rivera AM, Paéz-Melo MI, Mendéz-Paz F, AbrahamsChow N, Artunduaga-Trejos YP, Ordoñez J. Exploratory Study on the Evaluation of Health Risk in Lactating Mothers due to Contaminated Fish Consumption from the Cauca River, Valle del Cauca (Colombia). Ambiente y Desarrollo. 2018;22(43). DOI: https://doi.org/10.11144/Javeriana.ayd22-43.eeer

34. Díaz SM, Palma RM, Muñoz MN, Becerra-Arias C, Niño JAF. Factors associated with high mercury levels in women and girls from the Mojana region, Colombia, 2013-2015. Int J Environ Res Public Health. 2020;17(6):1827. DOI: https://doi.org/10.3390/ ijerph17061827 


\section{SUPPLEMENTAL MATERIAL}

Total mercury exposure risk and selenium content measuring on fishery products consumed by women of childbearing age from Bogota, Colombia

Table S1. Distribution of fishery products in the sample

\begin{tabular}{lcccccc}
\hline Product & Consumption frequency & Consumption score & Risk score & $\boldsymbol{\Sigma}$ & Total percentage & Number of specimens \\
\hline Tuna & 93.3 & 10 & 2 & 12 & 17 & 120 \\
Catfish & 62.7 & 9 & 2 & 11 & 16 & 110 \\
Tilapia & 44.5 & 8 & 1 & 9 & 13 & 90 \\
Bocachico & 28.6 & 7 & 2 & 9 & 13 & 90 \\
Nicuro & 28.4 & 6 & 1 & 7 & 10 & 70 \\
Sardine & 20.8 & 5 & 1 & 6 & 9 & 60 \\
Salmon & 9.9 & 4 & 1 & 5 & 7 & 50 \\
Pangasius & 8.9 & 3 & 2 & 5 & 7 & 50 \\
Mota & 6.9 & 2 & 2 & 4 & 6 & 40 \\
Trout & 3.7 & 1 & 1 & 2 & 3 & 100 \\
TOTAL & & & & 70 & & 700 \\
\hline
\end{tabular}

Note. The number of specimens per fishery product in the sample was determined through a stratified procedure in which a score of 1 to 10 was assigned based on the consumption frequency and, another 1 to 2 according to intake risk.

Table S2. Preset serving sizes for the assessed fishery products

\begin{tabular}{lccc}
\hline Product & Small portion $(\mathbf{g})$ & Medium portion $(\mathbf{g})$ & Large portion $(\mathbf{g})$ \\
\hline Tuna & 39 & 54 & 116 \\
Catfish & 130 & 160 & 385 \\
Tilapia & 220 & 345 & 546 \\
Bocachico & 207 & 670 & 820 \\
Nicuro & 58 & 77 & 111 \\
Sardine & 55 & 101 & 145 \\
Salmon & 125 & 476 & 755 \\
Pangasius & 92 & 103 & 118 \\
Mota & 282 & 427 & 473 \\
Trout & 219 & 365 & 543 \\
\hline
\end{tabular}

Note. Serving sizes were established to identify the average quantity consumed of each fishery product.

Table S3. Frequency factor

\begin{tabular}{lc}
\hline \multicolumn{1}{c}{ Consumption frequency } & Frequency factor \\
\hline Less than once a month & 0.017 \\
Once a month & 0.033 \\
2 or 3 times a month & 0.066 \\
Once a week & 0.140 \\
Twice a week & 0.290 \\
3 or 4 times a week & 0.420 \\
5 or 6 times a week & 0.710 \\
Once daily & 1 \\
Twice daily & 2 \\
3 or more times daily & 3 \\
\hline
\end{tabular}

Note. Frequency factor represents the periodicity of food intake normalized per daily unit time. 
Table S4. Mercury concentration in fishery products

\begin{tabular}{lccccc}
\hline \multicolumn{1}{c}{ Product } & $\mathbf{n}$ & Min & Max & Median & Mean $(\mathbf{C l}$ 95\%) \\
\hline Tuna & 120 & 0.0183 & 0.9196 & 0.1128 & $0.1882(0.1555,0.2208)$ \\
Catfish & 110 & 0.0050 & 2.0256 & 0.5818 & $0.6275(0.5512,0.7038)$ \\
Tilapia & 90 & 0.0025 & 0.0808 & 0.0177 & $0.0194(0.0168,0.0220)$ \\
Bocachico & 90 & 0.0071 & 0.5160 & 0.0374 & $0.0548(0.0397,0.0699)$ \\
Nicuro & 70 & 0.0115 & 0.1520 & 0.0460 & $0.0571(0.0497,0.0645)$ \\
Sardine & 60 & 0.0056 & 0.2926 & 0.0219 & $0.0313(0.0215,0.0412)$ \\
Salmon & 50 & 0.0022 & 0.2870 & 0.0216 & $0.0258(0.0148,0.0368)$ \\
Pangasius & 50 & 0.0010 & 0.7123 & 0.0042 & $0.0207(-0.0071,0.0485)$ \\
Mota & 40 & 0.1332 & 2.1515 & 0.7495 & $0.8166(0.6864,0.9469)$ \\
Trout & 20 & 0.0140 & 0.0770 & 0.0521 & $0.0502(0.0423,0.0582)$ \\
\hline
\end{tabular}

Note. Mercury content is expressed as milligram of element over kilogram of product $(\mathrm{mg} / \mathrm{kg})$.

Table S5. Selenium concentration in fishery products

\begin{tabular}{lccccc}
\hline \multicolumn{1}{c}{ Product } & $\mathbf{n}$ & Min & Max & Median & Mean $(\mathbf{C l}$ 95\%) \\
\hline Tuna & 120 & 0.1759 & 1.3812 & 0.4555 & $0.4908(0.4551,0.5266)$ \\
Catfish & 110 & 0.0100 & 0.9715 & 0.1472 & $0.1598(0.1361,0.1835)$ \\
Tilapia & 90 & 0.0620 & 0.3348 & 0.1406 & $0.1485(0.1396,0.1575)$ \\
Bocachico & 90 & 0.0720 & 1.8210 & 0.3020 & $0.4564(0.3748,0.5381)$ \\
Nicuro & 70 & 0.0860 & 2.3711 & 0.5500 & $0.6471(0.5500,0.7442)$ \\
Sardine & 60 & 0.0643 & 0.5252 & 0.2863 & $0.2943(0.2710,0.3176)$ \\
Salmon & 50 & 0.0366 & 0.6330 & 0.0984 & $0.1121(0.0888,0.1354)$ \\
Pangasius & 50 & 0.0117 & 0.1966 & 0.0949 & $0.1003(0.0884,0.1122)$ \\
Mota & 40 & 0.0477 & 0.3375 & 0.1398 & $0.1432(0.1268,0.1596)$ \\
Trout & 20 & 0.0523 & 0.9230 & 0.1019 & $0.1490(0.0663,0.2318)$ \\
\hline
\end{tabular}

Note. Selenium content is expressed as milligram of element over kilogram of product (mg/kg).

Table S6. Se:Hg molar ratio in fishery products

\begin{tabular}{lccccc}
\hline Product & $\mathbf{n}$ & Min & Max & Median & Mean $(\boldsymbol{C l}$ 95\%) \\
\hline Tuna & 120 & 1.19 & 69.51 & 10.18 & $12.17(10.35,14.00)$ \\
Catfish & 110 & 0.01 & 130.02 & 0.74 & $2.91(0.46,5.37)$ \\
Tilapia & 90 & 3.90 & 340.21 & 21.21 & $31.87(23.60,40.15)$ \\
Bocachico & 90 & 0.46 & 237.67 & 17.66 & $47.98(36.41,59.55)$ \\
Nicuro & 70 & 3.60 & 150.97 & 30.42 & $37.02(30.64,43.39)$ \\
Sardine & 60 & 0.56 & 80.70 & 34.90 & $35.38(31.11,39.66)$ \\
Salmon & 50 & 0.88 & 233.05 & 13.38 & $24.45(13.91,34.98)$ \\
Pangasius & 50 & 0.21 & 262.77 & 52.64 & $60.16(48.25,72.07)$ \\
Mota & 40 & 0.12 & 4.87 & 0.47 & $0.63(0.40,0.86)$ \\
Trout & 20 & 2.43 & 45.53 & 4.90 & $8.28(4.12,12.43)$ \\
\hline
\end{tabular}

Note. Molar ratio is the fraction of selenium moles over mercury moles. 
Table S7. Molar excess of selenium

\begin{tabular}{lccccc}
\hline Product & $\mathbf{n}$ & Min & Max & Median & Mean (Cl 95\%) \\
\hline Tuna & 120 & 0.0007 & 0.0166 & 0.0049 & $0.0053(0.0048,0.0057)$ \\
Catfish & 110 & -0.0100 & 0.0119 & -0.0007 & $-0.0011(-0.0017,-0.0006)$ \\
Tilapia & 90 & 0.0007 & 0.0042 & 0.0017 & $0.0018(0.0017,0.0019)$ \\
Bocachico & 90 & -0.0014 & 0.0229 & 0.0035 & $0.0055(0.0045,0.0066)$ \\
Nicuro & 70 & 0.0009 & 0.0298 & 0.0067 & $0.0079(0.0067,0.0091)$ \\
Sardine & 60 & -0.0006 & 0.0065 & 0.0035 & $0.0036(0.0033,0.0039)$ \\
Salmon & 50 & -0.0002 & 0.0080 & 0.0011 & $0.0013(0.0010,0.0016)$ \\
Pangasius & 50 & -0.0028 & 0.0024 & 0.0012 & $0.0012(0.0010,0.0014)$ \\
Mota & 40 & -0.0088 & 0.0026 & -0.0019 & $-0.0023(-0.0029,-0.0016)$ \\
Trout & 20 & 0.0004 & 0.0114 & 0.0011 & $0.0016(0.0006,0.0027)$ \\
\hline
\end{tabular}

Note. Molar excess of selenium was calculated from the subtraction of mercury moles from selenium moles. The values presented in the table are expressed as mol of element over kilogram of product $(\mathrm{mol} / \mathrm{kg})$. 